\title{
Pattern and pathways for mercury lifespan bioaccumulation in Carcinus maenas
}

\author{
J.P. Coelho ${ }^{\text {a,* }}$, A.T. Reis ${ }^{\text {a }}$, S. Ventura ${ }^{\text {a }}$, M.E. Pereira ${ }^{\text {a }}$, A.C. Duarte ${ }^{\text {a }}$, M.A. Pardal ${ }^{\text {b }}$ \\ ${ }^{a}$ CESAM - Chemistry Department, Campus de Santiago, University of Aveiro, 3810-193 Aveiro, Portugal \\ ${ }^{\mathrm{b}}$ IMAR - Institute of Marine Research, Zoology Department, University of Coimbra, 3004-517 Coimbra, Portugal
}

\section{A R T I C L E I N F O}

\section{Keywords:}

Mercury

Organic mercury

Carcinus maenas

Lifespan bioaccumulation pattern

Management

\begin{abstract}
A B S T R A C T
Carcinus maenas is an important and exploited natural resource in temperate estuaries, being consumed by local populations and also used as fish bait. Through bioaccumulation and bioamplification processes occurring in polluted estuarine ecosystems, this species may directly or indirectly represent a major pathway for Human contamination. No information is available on the overall lifespan bioaccumulation pattern of mercury for this species, which would be an invaluable tool for assessing the risks associated with $C$. maenas harvest in contaminated areas. Taking that in mind, the main objectives of this work were to clarify the lifespan bioaccumulation pattern of mercury for this species. A consistent lifespan accumulation pattern was found for this species, both for total and organic mercury, and coherent differences were found between genders, suggesting different physiological responses to contamination. From our results two scenarios emerge: (a) for low mercury contamination areas where the diet is the major pathway for metal uptake, with higher levels in muscle and hepatopancreas (twice as high as in gills) and higher organic mercury fractions (as high as $80-90 \%$ in muscle), crabs bioaccumulate with age and (b) on high contaminated areas, environmental exposure is predominant, with higher levels found in gills (reaching $0.8 \mathrm{mg} \mathrm{kg}^{-1}$ ), lower organic fractions and no mercury increment with age. Detoxification strategies, dietary differences and species mobility may account for these two accumulation patterns.
\end{abstract}

(c) 2008 Elsevier Ltd. All rights reserved.

\section{Introduction}

Mercury is a well-known, highly deleterious environmental pollutant with recognized mutagenic and teratogenic effects (Calderón et al., 2003; Tchounwou et al., 2003). It is accumulated by many aquatic organisms, transferred and magnified along the trophic chain (Watras and Bloom, 1992; Laporte et al., 1997; Lawson and Mason, 1998), eventually finding its way to economically important species and ultimately to Humans. The trace metal content of organisms is therefore a common tool in monitoring programs of metal pollution in the marine environment, since it provides a time-integrated measure of metal availability (Saiz-Salinas et al., 1996). Focus has been given to macroinvertebrate species, namely benthic bivalve and gastropod molluscs, found to be effective bioaccumulators (Byrne and O'Halloran, 2001; Liang et al., 2004; Roméo et al., 2005; Coelho et al., 2006a). Differences in experimental design (e.g. size classes defined, gender used, etc.) from study to study are common, even when working with the same species, and this poses serious restrictions for research intercomparison. Also, given that many of the monitored species are of commercial interest, and legislation on the commercial size of each species varies depending on location, it is important to

\footnotetext{
* Corresponding author. Tel.: +351 234370737; fax: +351 234370084.

E-mail address: jpcoelho@ua.pt (J.P. Coelho).
}

have some knowledge on the lifespan and on the annual bioaccumulation patterns of each species. Data on the clam Scrobicularia plana (Coelho et al., 2006b) suggests mercury accumulation to be a function of suspended particulate matter (SPM) metal content. The rather stable ratio found between SPM mercury concentrations and S. plana annual bioaccumulation rates may allow extrapolating results from a specific size class to commercially available size classes, and hence assess the risk associated with the consumption by Humans at any given location. Nevertheless, more information is needed, since physiologic responses to contamination are species specific and estuarine resources other than $S$. plana are exploited in temperate climates. Predator species, both vertebrate and invertebrate, will be subject to biomagnification processes (mainly of methylmercury) along the food web and are likely to have higher mercury body burdens (Andres et al., 2002; Laporte et al., 2002) being a health concern and justifying further research in the area.

The European shore crab Carcinus maenas has a wide geographical distribution, inhabiting hard and soft inter-tidal and sub-tidal zones of sheltered shores (Baeta et al., 2005). It is an aggressive and voracious predator, thought to be an important feature in structuring marine and estuarine benthic communities (Raffaelli et al., 1989). This species has a lifespan of 3-4 years, and sexual maturity is reached at $\approx 3 \mathrm{~cm}$ carapace length, corresponding to $1+$ year-old adult individuals. At temperate latitudes reproduction 
is continuous, and the recruitment period extends throughout several months (Baeta et al., 2005). This species is one of the most important and exploited natural resources in temperate estuarine systems, and therefore represent a major pathway for Human contamination. Most of the previous research on this species consist of laboratory studies, focusing on mercury mediated osmoregulatory impairment (Péqueux et al., 1996), the combined effects of salinity and $\mathrm{pH}$ on the bioaccumulation of mercury (Laporte et al., 1997) or feeding experiments using mercury contaminated food (Evans et al., 2000). Studies on a different decapod crustacean, the blue crab, focused on the transport mechanisms and fluxes of mercury across the membranes (gills and intestine) and suggest that inorganic and organic mercury uptake into the gills and intestine of this invertebrate is by a variety of pathways, both active and passive (Andres et al., 2002; Laporte et al., 2002). Less information is available on field accumulation studies (Pereira et al., 2006), and no information is available on the overall lifespan bioaccumulation pattern of this species, which would be an invaluable tool for decision makers when assessing the risks associated with $C$. maenas harvest in contaminated areas.

Taking that in mind, the main objectives of this work were: (i) to document in situ mercury accumulation along the benthic lifespan of the crab Carcinus maenas both in total and organic forms, (ii) to evaluate the existence of differential organ accumula- tion, (iii) to compare male and female accumulation patterns and, as a result of the latter, (iv) to clarify the lifespan bioaccumulation pattern of this species.

\section{Materials and methods}

\subsection{Study site}

The study was conducted in the Ria de Aveiro coastal lagoon, north western coast of Portugal (Fig. 1), which since the 1950's has continuously received mercury effluents from a chlor-alkali industry, inducing an environmental contamination gradient inside the lagoon (Pereira et al., 1998a). Mercury storage in the system is estimated to be $33 \times 10^{3} \mathrm{~kg}$, of which $77 \%$ are stored in the channel flowing from the mercury source and in the Laranjo basin, the area comprising sampling sites A1-A5 (Pereira et al., 1998a).

Eight sampling locations (A1-A13) were selected along the lagoon with special focus on the most contaminated area, the Laranjo basin (stations A1-A5), near the outlet of the industrial mercury discharges. In addition, one sampling station was selected in the Mondego estuary (A15), $60 \mathrm{~km}$ south from the Ria. This station was considered to have pristine conditions referring to heavy metals (Vale et al., 2002) and served as a reference site, for comparison purposes.
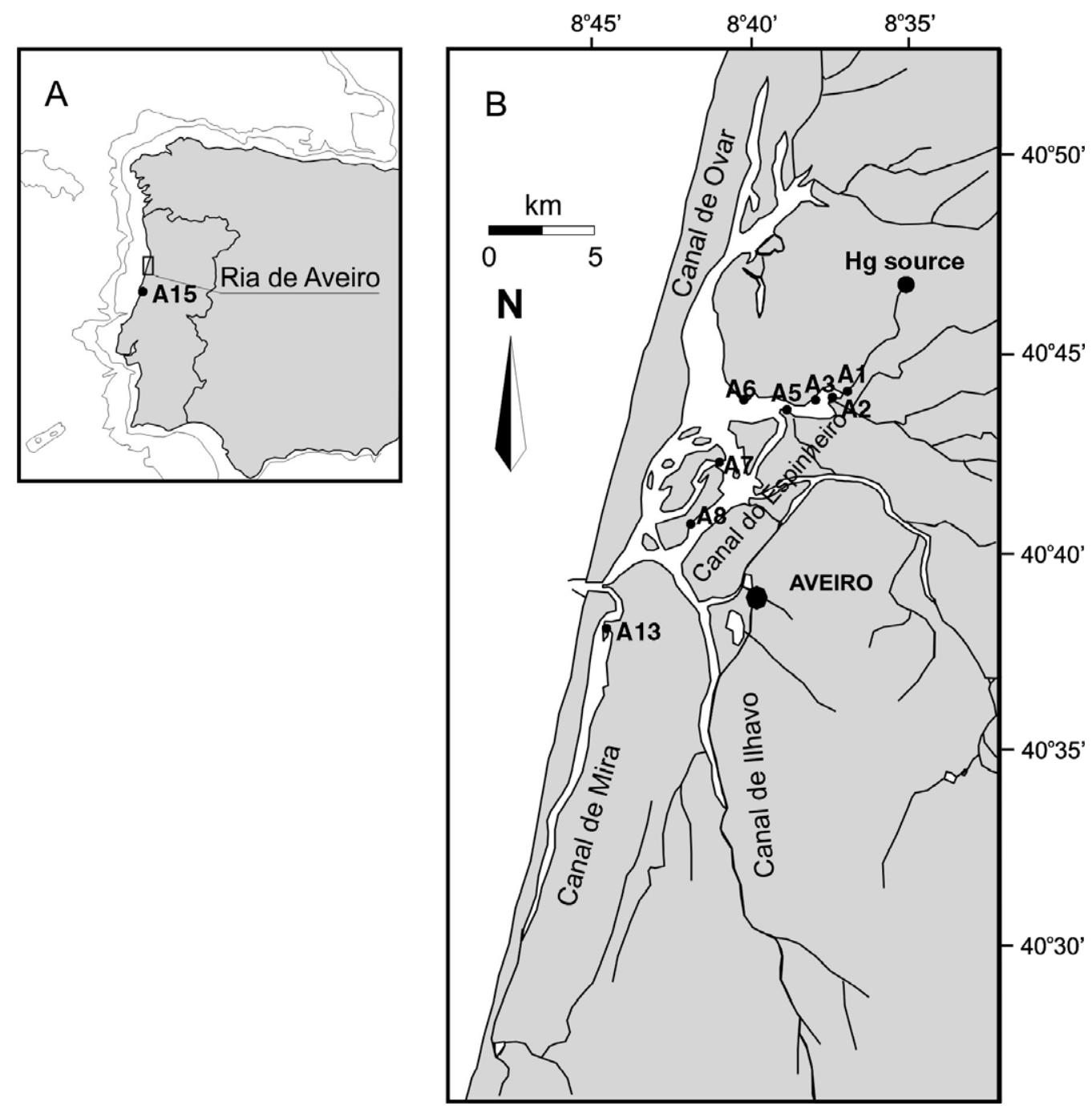

Fig. 1. The Ria de Aveiro coastal lagoon with the sampling sites indicated. 
At each site, a composite sediment sample was obtained from the top $30 \mathrm{~cm}$, consisting of 5 replicate cores $(15 \mathrm{~cm}$ diameter) pooled together in order to account for within-site variability. On arrival to the laboratory, sediments were oven-dried to constant weight at $60{ }^{\circ} \mathrm{C}$, homogenized and sieved through a $1 \mathrm{~mm}$ sieve before storage until analysis. Water samples were collected from intertidal water pools at each site in acid-washed plastic bottles and kept on ice during transportation to the laboratory, where they were filtered through $0.45 \mu \mathrm{m}$ Millipore cellulose acetate membrane filters, acidified to $\mathrm{pH}<2$ and stored at $4{ }^{\circ} \mathrm{C}$ until analysis. Filters were oven-dried at $60{ }^{\circ} \mathrm{C}$ and digested with $\mathrm{HNO}_{3} 4 \mathrm{~mol} \mathrm{~L}^{-1}$ for determination of the total mercury concentration in suspended particulate matter (for detailed information on method see Pereira et al., 1998b).

Table 1

Total mercury in sediments and suspended particulate matter $\left(\mathrm{mg} \mathrm{kg}^{-1}\right)$, reactive and total dissolved mercury (ng L $\left.{ }^{-1}\right)(\mathrm{mean} \mathrm{values} \pm \mathrm{std}$. dev.)

\begin{tabular}{|c|c|c|c|c|}
\hline Station & Sediment $\mathrm{Hg}\left(\mathrm{mg} \mathrm{kg}^{-1}\right)$ & Reactive dissolved $\mathrm{Hg}\left(\mathrm{ngL}^{-1}\right)$ & Total dissolved $\mathrm{Hg}\left(\mathrm{ngL}^{-1}\right)$ & Suspended particulate matter $\mathrm{Hg}\left(\mathrm{mg} \mathrm{kg}^{-1}\right)$ \\
\hline A1 & $51.7 \pm 4.8$ & $60.5 \pm 9.6$ & $275.4 \pm 12.6$ & $25.8 \pm 0.4$ \\
\hline $\mathrm{A} 2$ & $6.8 \pm 0.3$ & $15.8 \pm 1.0$ & $73.2 \pm 4.0$ & $20.1 \pm 2.6$ \\
\hline A3 & $5.2 \pm 0.1$ & $24.0 \pm 2.3$ & $97.8 \pm 0$ & $9.0 \pm 0.5$ \\
\hline A5 & $6.2 \pm 0.1$ & $9.0 \pm 1.7$ & $34.4 \pm 3.4$ & $8.9 \pm 0.5$ \\
\hline A6 & $0.4 \pm 0$ & $2.9 \pm 0.4$ & $10.0 \pm 1.5$ & $1.1 \pm 0$ \\
\hline A7 & $0.1 \pm 0$ & $4.0 \pm 0.6$ & $6.8 \pm 1.7$ & $0.7 \pm 0.1$ \\
\hline A8 & $0.2 \pm 0$ & $2.6 \pm 0.3$ & $4.4 \pm 0.7$ & $0.8 \pm 0.1$ \\
\hline A13 & $0.2 \pm 0$ & $0.6 \pm 0.3$ & $1.0 \pm 0.6$ & $0.6 \pm 0.2$ \\
\hline A15 & $0.1 \pm 0$ & $1.5 \pm 0.4$ & $4.6 \pm 1.3$ & $1.2 \pm 0.5$ \\
\hline
\end{tabular}

Females
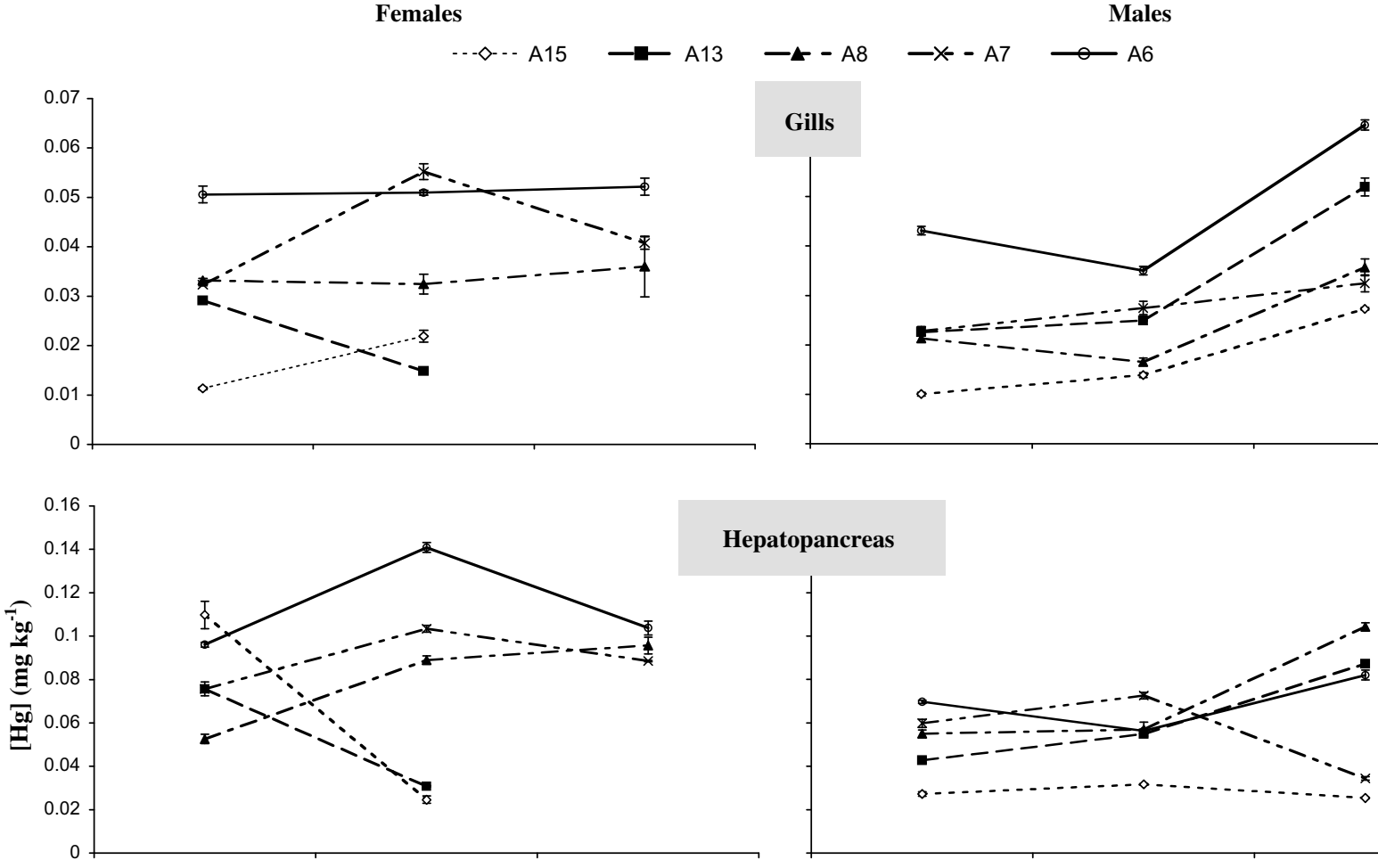

epatopancreas
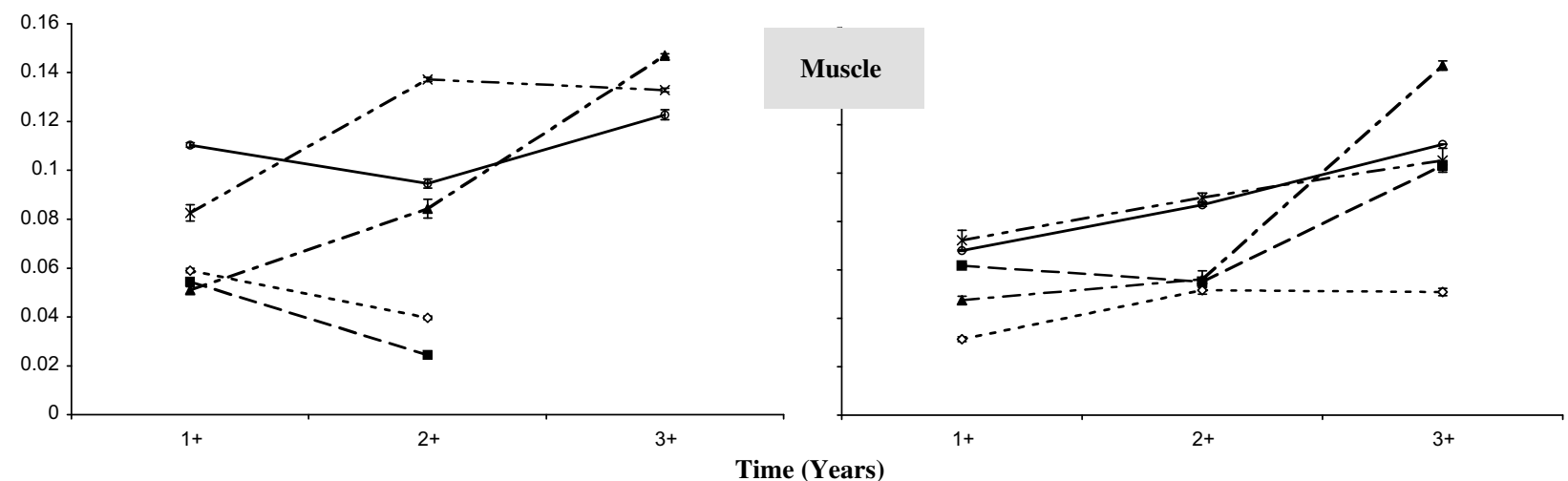

Fig. 2a. Total mercury concentrations $\left(\mathrm{mg} \mathrm{kg}^{-1}\right)$ in the different tissues and genders of $1+, 2+$ and $3+$ year-old Carcinus maenas in low contamination sites. 
Carcinus maenas of three size classes $(<3.5,3.5-4.5$ and $>4.5 \mathrm{~cm}$, corresponding to $1+, 2+$ and $3+$ year-old individuals) were captured in low water conditions using baited circular drop nets. On arrival to the laboratory, specimens were measured (cephalothorax width), weighted (total fresh weight), grouped in the specified size

Table 2

Annual accumulation rates $\left(\mathrm{mg} \mathrm{Hg} \mathrm{kg}^{-1} \mathrm{y}^{-1}\right.$, extrapolated from the regression equations) in the different tissues and genders of $1+, 2+$ and $3+$ year-old Carcinus maenas

\begin{tabular}{lccllllrr}
\hline & Guills & & & \multicolumn{2}{l}{ Hepatopancreas } & & \multicolumn{2}{l}{ Muscle } \\
\cline { 2 - 3 } & Female & Male & & Female & Male & & Female & Male \\
\hline A1 & $\mathbf{0 . 1 3}$ & 0.06 & & 0.04 & $-\mathbf{0 . 1 5}$ & & 0.16 & $\mathbf{0 . 0 4}$ \\
A2 & $\mathbf{0 . 0 2}$ & -0.04 & & $\mathbf{0 . 0 5}$ & $-\mathbf{0 . 0 4}$ & & -0.004 & -0.02 \\
A3 & $\mathbf{0 . 1 0}$ & $\mathbf{0 . 0 8}$ & & $\mathbf{0 . 0 3}$ & -0.05 & & 0.008 & 0.02 \\
A5 & -0.01 & & & 0.02 & & & 0.02 & \\
A6 & $\mathbf{0 . 0 0 0 8}$ & 0.01 & & $\mathbf{0 . 0 0 4}$ & 0.006 & & 0.006 & $\mathbf{0 . 0 2}$ \\
A7 & 0.004 & $\mathbf{0 . 0 0 5}$ & & 0.006 & -0.01 & & $\mathbf{0 . 0 2}$ & $\mathbf{0 . 0 2}$ \\
A8 & 0.001 & 0.007 & & 0.02 & $\mathbf{0 . 0 2}$ & & $\mathbf{0 . 0 5}$ & $\mathbf{0 . 0 5}$ \\
A13 & & $\mathbf{0 . 0 1}$ & & $\mathbf{0 . 0 2}$ & & $\mathbf{0 . 0 2}$ \\
A15 & & $\mathbf{0 . 0 1}$ & & -0.0009 & & $\mathbf{0 . 0 1}$ \\
\hline
\end{tabular}

Values not in bold are weak correlations. classes ( $n=10$ to $n=15$ each) and dissected with tissue differentiation (muscle, hepatopancreas, gills and exoskeleton). Each sample was then homogenised, freeze-dried at $-50{ }^{\circ} \mathrm{C}$ and 0.06 bars, and homogenized for analysis.

\subsection{Laboratory procedures}

Sediment and biological samples were analyzed for total mercury by thermal decomposition atomic absorption spectrometry with gold amalgamation, using a LECO AMA-254 (Advanced Mercury Analyzer).

Dissolved reactive mercury and suspended particulate matter (SPM) mercury analyses were performed by cold-vapor atomic fluorescence spectrometry (CV-AFS) using a PSA model Merlin 10.023 equipped with a detector PSA model 10.003 , with tin chloride as reducing agent ( $2 \%$ in $10 \% \mathrm{HCl}$ ). Organic mercury determinations in biological tissues were determined through triplicate digestion with a mixture of $18 \% \mathrm{KBr}$ in $5 \% \mathrm{H}_{2} \mathrm{SO}_{4}$, followed by extraction of organic mercury into toluene (for more information on method see Válega et al., 2006).
Females

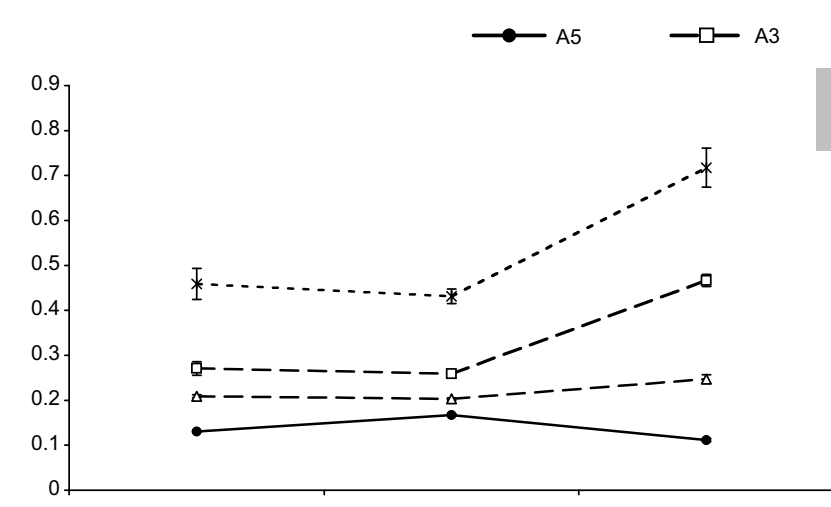

Males

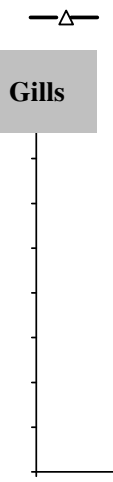

$--*--A 1$

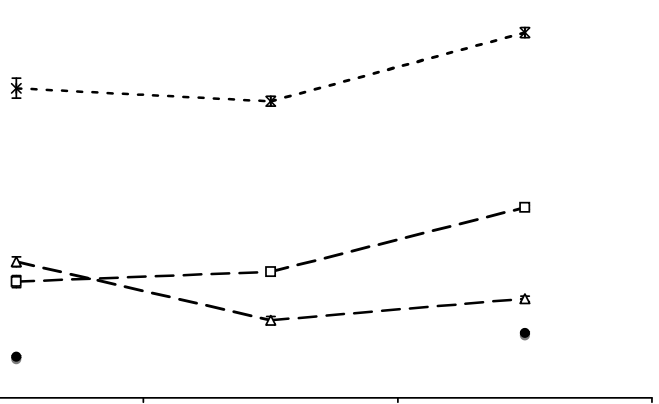

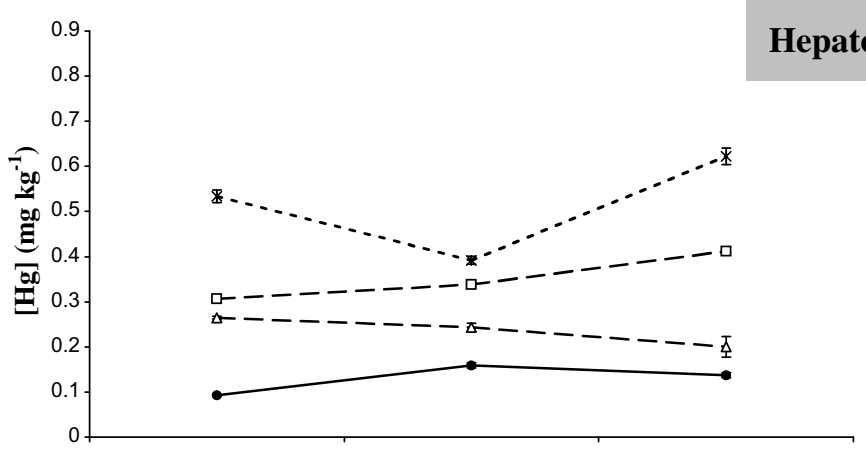

Hepatopancreas

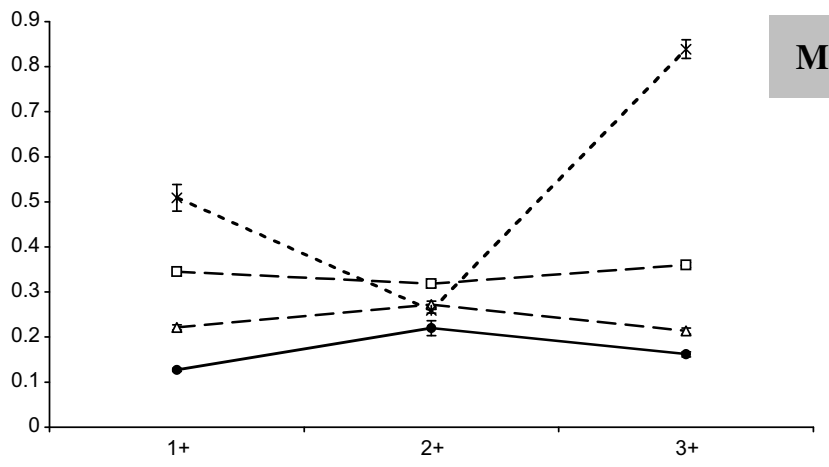

\section{Muscle}

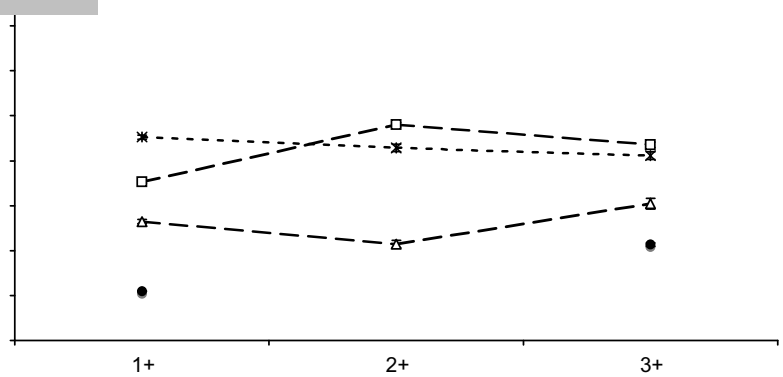

Time (Years)

Fig. 2b. Total mercury concentrations $\left(\mathrm{mg} \mathrm{kg}^{-1}\right)$ in the different tissues and genders of $1+, 2+$ and $3+$ year-old Carcinus maenas in high contamination sites. 
Analytical quality control was performed by using certified reference material (CRM). The CRM used for sediments were IAEA-356 and MESS-2 (marine sediments), while for biota TORT2 (lobster hepatopancreas) was used. The results were corrected according to the daily recovery percentage of the CRM analyses. The values obtained for the whole of the CRM analysis ranged from $81 \%$ to $102 \%$ (MESS-2: $81 \pm 3 \%$; IAEA-356: $98 \pm 1 \%$; TORT-2: $102 \pm 2 \%$ (average \pm st. dev.)). Analyses were always performed in triplicate, and the coefficient of variation between replicates never exceeded $10 \%$. Reference material TORT-2 was used to validate organic mercury analyses, and an extraction efficiency of roughly $80 \%$ was achieved.

\section{Results}

\subsection{Environmental contamination}

Mercury in water (dissolved and suspended particulate matter) and total mercury in sediments were low in most sampling stations, except in the most contaminated area (Laranjo basin, stations A1 to A5), where concentrations reached as high as $50 \mathrm{mg} \mathrm{kg}^{-1}$ in sediments, $60 \mathrm{ng} \mathrm{L}^{-1}$ in water and $25 \mathrm{mg} \mathrm{kg}^{-1}$ in SPM. For the remnant of the sampled system, mercury contamination was comparable to the reference site (A15) (Table 1). So, two distinct scenarios are present in the Aveiro lagoon where environmental mercury contamination problems seem therefore to be confined to the Laranjo basin.

\subsection{Total mercury accumulation in Carcinus maenas}

Mercury accumulation in C. maenas was found to follow the trend of environmental contamination, and hence results were analyzed separately for the downstream, low contaminated area and the most impacted upper reaches of the system.

In the downstream areas, mercury levels were found to be comparable to the reference site (Fig. 2a), especially site A13 which can be considered as a within system reference site in terms of $C$. maenas mercury contamination. Mercury levels tended to increase with age regardless of gender, except for the two least contaminated sites where mercury concentrations in females decreased with increasing size. Differential tissue contamination was observed, since mercury was found to occur preferably in muscle and hepatopancreas, usually twice as contaminated as gill tissue. Annual bioaccumulation rates (extrapolated from the regression slopes, Table 2) never exceeded $0.05 \mathrm{mg} \mathrm{Hg} \mathrm{kg}^{-1} \mathrm{y}^{-1}$, and where found to be twice as high for muscle tissue when compared to the gills. Stronger correlations where found between tissue mercury levels and age for males, which seem to accumulate mercury more constantly than females in this area.

In the contaminated area, very high mercury levels were recorded in $C$. maenas tissues, of nearly $1 \mathrm{mg} \mathrm{kg}^{-1}$ in wet weight (Fig. 2b), corresponding to twice the permitted threshold concentration for Human consumption. Here, no consistent pattern of accumulation with age was observed except for gill tissue, contrary to what was observed in the low contaminated areas. A more evenly distribution of mercury among different organs was found due to an increase in the mercury fraction associated with gill tissue. Regressions between mercury levels and age were weak in this area except for gill tissue, where annual accumulation rates reached as high as $0.13 \mathrm{mg} \mathrm{Hg} \mathrm{kg}^{-1} \mathrm{y}^{-1}$ (Table 2), nevertheless about half of what was found for Scrobicularia plana in the same area $\left(0.25 \mathrm{mg} \mathrm{Hg} \mathrm{kg}^{-1} \mathrm{y}^{-1}\right.$, Coelho et al., 2006b). No consistent net annual accumulation was observed for both hepatopancreas and muscle tissue in this area, and decontamination was frequently observed to occur with age.
From plotting male to female mercury concentrations for each tissue (Fig. 3), it was observed that females tend to accumulate more mercury than males in less contaminated areas, whereas in high environmental contamination sites this behaviour was reversed.

Considering the exoskeleton mercury concentrations, levels were considerably lower (always below $0.5 \mathrm{mg} \mathrm{kg}^{-1}$ dry weight), no consistent increment with age was found and results were generally similar between genders. This was somewhat predictable, since through periodic moulting, exoskeleton age will be similar regardless of crab size, which therefore explains the lack of bioaccumulation with age and differences between genders. Bioconcentration factors calculated with suspended particulate matter concentrations were rather stable, suggesting mercury levels in the carapace to be controlled by physical processes and environmental contamination rather than some biological control or mercury mobilization process to use moulting as a detoxification process.

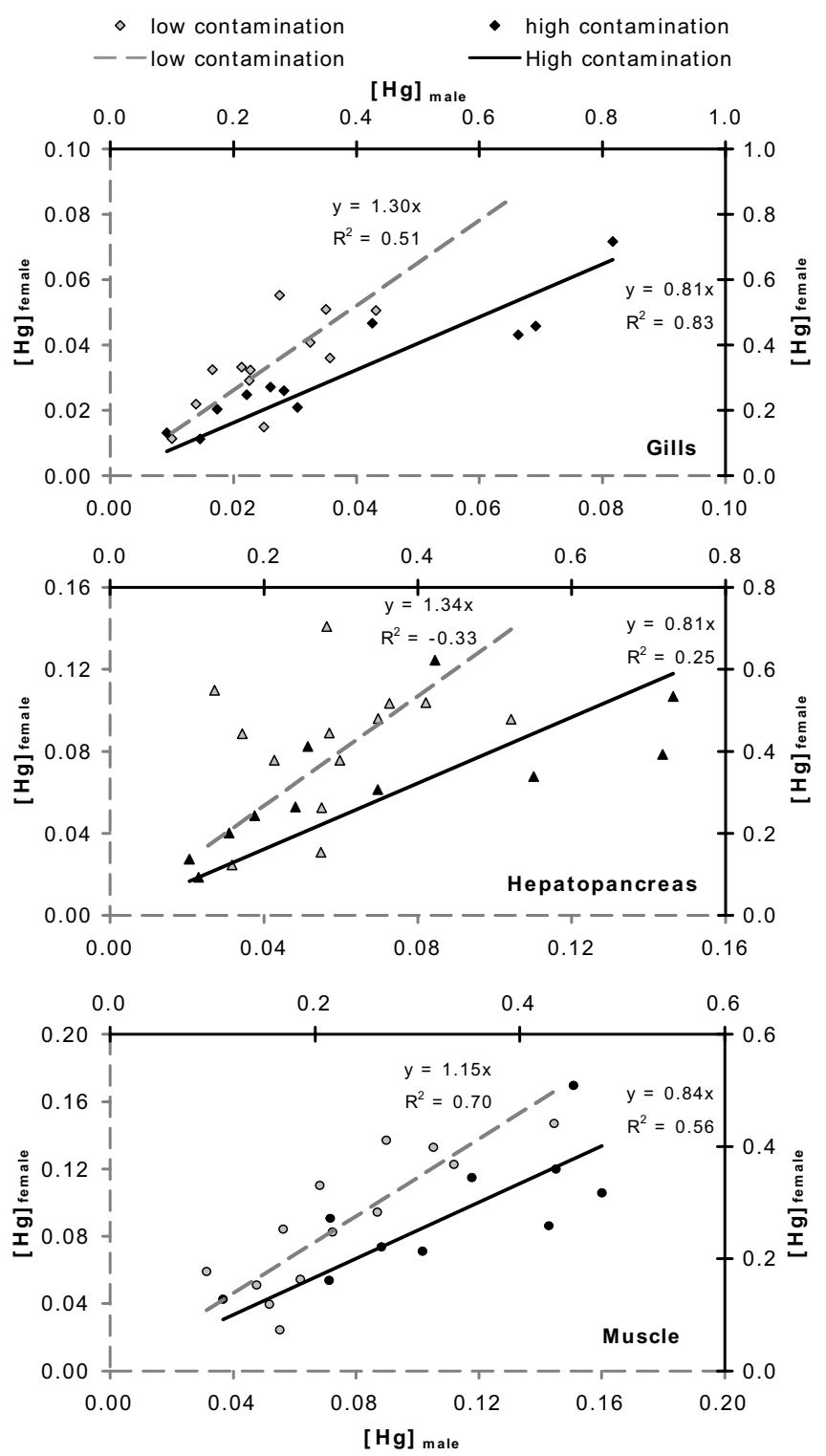

Fig. 3. Male to female mercury concentrations $\left(\mathrm{mg} \mathrm{kg}^{-1}\right)$ for gill, hepatopancreas and muscle tissue in low (dashed, grey regression line and axes) and high (black regression line and axes) contamination sites. 

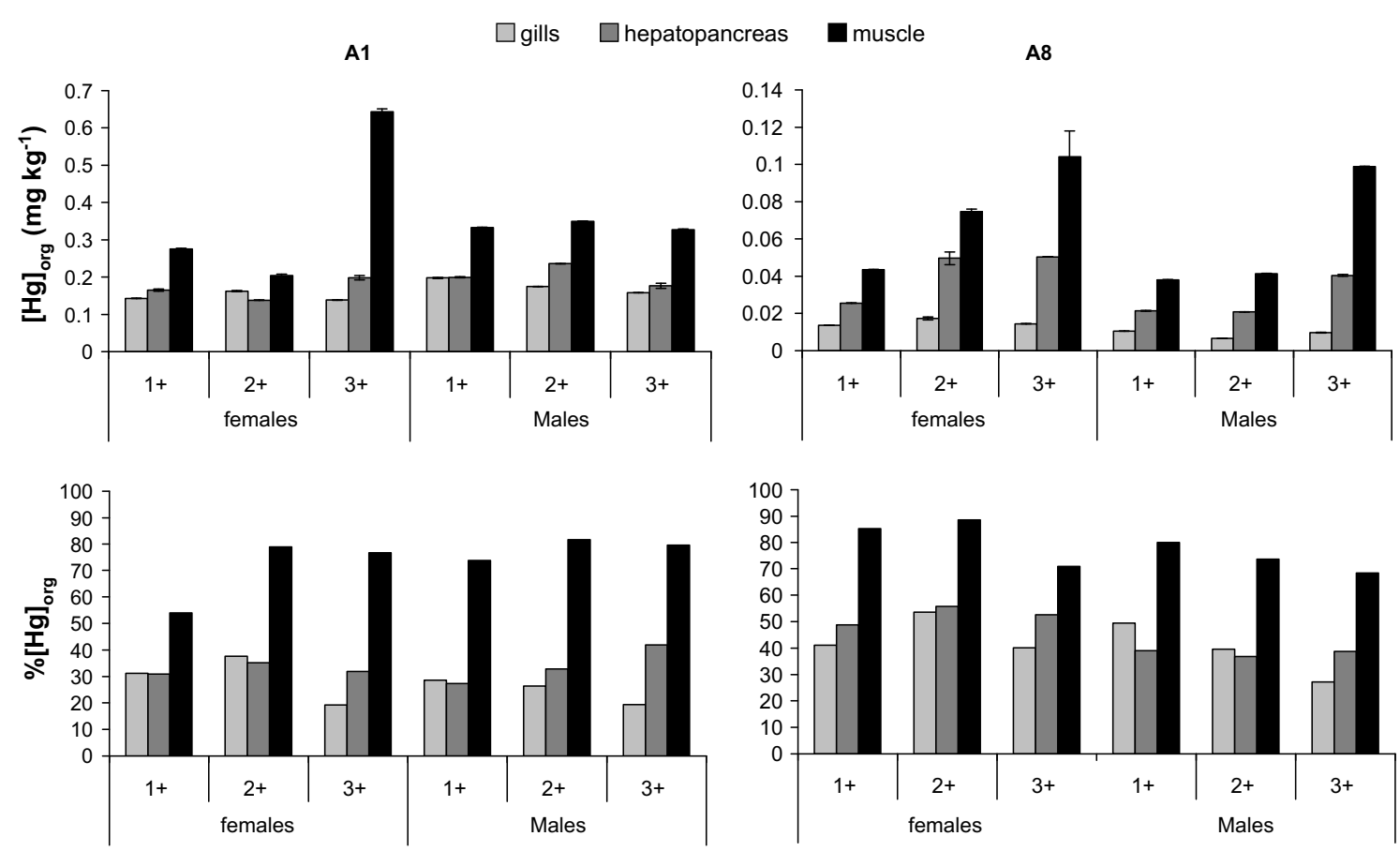

Fig. 4. Organic mercury concentrations $\left(\mathrm{mg} \mathrm{kg}^{-1}\right)$ and organic mercury percentage in the different tissues and genders of $1+, 2+$ and $3+$ year-old Carcinus maenas.

\subsection{Organic mercury accumulation in C. maenas}

Organic mercury was analyzed in samples from one location in each area (Fig. 4). Results were found to follow the same trend as total mercury, with increasing organic mercury concentrations with age in the low contaminated area but not in the highly contaminated area (mind the different scaling in Fig. 4). For all samples, muscle had the highest percentage of organic mercury, reaching as high as $90 \%$ of total mercury concentration (Fig. 4). The organic mercury fraction for all tissues, size classes and genders in the low contaminated area were higher than in the most contaminated site, and growth dilution was observed there, mainly for males.

\section{Discussion}

From our results, two distinct scenarios emerge for mercury accumulation in the shore crab $C$. maenas. In low contamination areas there is a preferential accumulation in internal organs such as muscle and hepatopancreas, which together with the higher organic mercury content, suggest the major pathway for contamination to be the diet. Contribution from environmental contamination (namely the dissolved fraction) seems low, reflected by the reduced mercury burden in gill tissue. It is known that mercury biomagnifies along food webs (Watras and Bloom, 1992; Lawson and Mason, 1998) and that higher trophic level organisms accumulate mercury mostly from food (Evans et al., 2000), hence even in low contamination areas dietary items will be enriched in mercury, and mainly in organic form, which is the most prone to bioaccumulate (Lawson and Mason, 1998).

In the low contamination area, annual bioaccumulation rates reached as high as $0.05 \mathrm{mg} \mathrm{Hg} \mathrm{kg}^{-1} \mathrm{y}^{-1}$ for muscular tissue, quite higher than what was observed for Scrobicularia plana in the contaminated site A5 $\left(0.035 \mathrm{mg} \mathrm{Hg} \mathrm{kg}^{-1} \mathrm{y}^{-1}\right)$ and similar to site A4 $\left(0.06 \mathrm{mg} \mathrm{Hg} \mathrm{kg}^{-1} \mathrm{y}^{-1}\right)$ (Coelho et al., 2006b). These results can be considered normal, since $C$. maenas is a top predator species. This accumulation pattern was more evident in males than females, despite females having higher mercury burdens in this area.
In highly contaminated areas, on the contrary, environmental exposure (mainly to inorganic mercury) seems to be the prominent pathway of incorporation, reflected by the larger proportion of mercury in the gills exposed to dissolved and particulate mercury, and a lower organic mercury percentage in all tissues. The form in which the mercury is taken in by crabs impacts on its internal fate, and an accumulation in the gills has been associated with a higher intake of inorganic mercury, as the gills are in contact mostly with the dissolved and particulate species in water (Laporte et al., 1997). Here, accumulation with age was observed only in the gills, and annual accumulation rates never exceeded $0.13 \mathrm{mg} \mathrm{Hg} \mathrm{kg}^{-1} \mathrm{y}^{-1}$, quite low compared to what was found for S. plana $\left(0.25 \mathrm{mg} \mathrm{Hg} \mathrm{kg}^{-1} \mathrm{y}^{-1}\right.$, Coelho et al., 2006b).

The uptake pathways of mercury in the blue crab were studied by Andres et al. (2002) and Laporte et al. (2002) who reported that inorganic and organic mercury uptake across the gill and intestinal tissues of the crab are rapid and of the same order of magnitude, and that this is due to the relatively unspecific nature of the uptake, with the potential for accumulation of mercury by a variety of pathways. These studies support the idea that mercury uptake potential is similar despite the gender of the organism, which contrasts with what was observed in the field in this study. Taking this into account, the differential mercury accumulation between genders in low and high contamination areas is probably due to external factors, such as behavioural differences in mobility (male crabs are more mobile than females, which tend to spend more time in burrows) and physiological differences related with reproduction. Further research is needed, however, to better clarify the underlying reasons for these differences.

In addition to the different pathway of exposure between the areas with different contamination levels, distinct lifespan bioaccumulation patterns were found, since in low contamination sites an accumulation with age was visible (in males) while in high contamination area this trend was not observed. A few explanatory hypotheses may be suggested for the different bioaccumulation patterns found, but there is still no certainty of why this occurs. One possible explanation is the triggering of detoxification strategies when subject to high mercury contamination, such as 
metallotionein production. However, there are still uncertainties about mercury mediated metallotionein production (Amiard et al., 2006), and especially about the fate of the detoxified metal forms, because if they are simply stored in the tissues they would still be quantified.

In addition, dietary differences may partially account for the lifespan patterns of accumulation, especially if associated with migrations to and from other areas of the system. Carcinus maenas is known to migrate from the upper reaches of estuaries to downstream areas in the winter, to avoid salinity related stress (Baeta et al., 2005; Pereira et al., 2006) and reduced food availability due to lower benthic macroinvertebrate densities in winter months (Abrantes et al., 1999; Verdelhos et al., 2005). The time spent in low contamination areas as well as the less contaminated dietary items consumed during that time may explain the bias observed. The reduced mobility of smaller crabs would result in a higher exposure to contamination at a young age in situations that promote mercury accumulation. With increasing size and enhanced mobility, individuals would be subject to high contamination for shorter periods, resulting in reduced net accumulation and the observed decrease in tissue metal content.

As a conclusion, a consistent lifespan accumulation pattern was found for this species, both for total and organic mercury depending on the degree of the environmental contamination. Moreover the differential tissue contamination seems dependent on the major pathway of exposure. Further research is needed to better understand the mechanisms controlling mercury bioaccumulation, in a continuous search for a management tool to predict mercury contamination risks.

\section{Acknowledgements}

This study was supported by the Portuguese Foundation for Science and Tecnology through the POCTI - 2010 Formação Avançada para a Ciência - Medida IV.3 (Portuguese FCT) via a PhD Grant (SFRH/BD/19509/2004) (J.P. Coelho).

\section{References}

Abrantes, A., Pinto, F., Moreira, M.H., 1999. Ecology of the polychaete Nereis diversicolor in the canal de Mira (Ria de Aveiro, Portugal): population dynamics, production and oogenic cycle. Acta Oecologica 20, 267-283.

Amiard, J.-C., Amiard-Triquet, C., Barka, S., Pellerin, J., Rainbow, P.S., 2006 Metallothioneins in aquatic invertebrates: their role in metal detoxification and their use as biomarkers. Aquatic Toxicology 76, 160-202.

Andres, S., Laporte, J.M., Mason, R.P., 2002. Mercury accumulation and flux across the gills and the intestine of the blue crab (Callinectes sapidus). Aquatic Toxicology 56, 303-320.

Baeta, A., Cabral, H.N., Neto, J.M., Marques, J.C., Pardal, M.A., 2005. Biology, population dynamics and secondary production of the green crab Carcinus maenas (L.) in a temperate estuary. Estuarine, Coastal and Shelf Science 65, 4352.

Byrne, P.A., O'Halloran, J., 2001. The role of bivalve molluscs as tools in estuarine sediment toxicity testing: a review. Hydrobiologia 465, 209-217.
Calderón, J., Ortiz-Pérez, D., Yáñez, L., Díaz-Barriga, F., 2003. Human exposure to metals. Pathways of exposure, biomarkers of effect, and host factors. Ecotoxicology and Environmental Safety 56, 93-103.

Coelho, J.P., Pimenta, J., Gomes, R., Barroso, C.M., Pereira, M.E., Pardal, M.A., Duarte, A., 2006a. Can Nassarius reticulatus be used as a bioindicator for $\mathrm{Hg}$ contamination? Results from a longitudinal study of the Portuguese coastline. Marine Pollution Bulletin 52, 674-680.

Coelho, J.P., Rosa, M., Pereira, M.E., Duarte, A., Pardal, M.A., 2006b. Pattern and annual rates of Scrobicularia plana mercury bioaccumulation in a human induced mercury gradient (Ria de Aveiro, Portugal). Estuarine Coastal and Shelf Science 69, 629-635.

Evans, D.W., Kathman, R.D., Walker, W.W., 2000. Trophic accumulation and depuration of mercury by blue crabs (Callinectes sapidus) and pink shrimp (Penaeus duorarum). Marine Environmental Research 49, 419-434.

Laporte, J.M., Ribeyre, F., Truchot, J.P., Boudou, A., 1997. Combined effects of water $\mathrm{pH}$ and salinity on the bioaccumulation of inorganic mercury and methylmercury in the shore crab Carcinus maenas. Marine Pollution Bulletin 34, 880-893.

Laporte, J.M., Andres, S., Mason, R.P., 2002. Effect of ligands and other metals on the uptake of mercury and methylmercury across the gills and the intestine of the blue crab (Callinectes sapidus). Comparative Biochemistry and Physiology Part C 131, 185-196.

Lawson, N.M., Mason, R.P., 1998. Accumulation of mercury in estuarine food chains. Biogeochemistry 40, 235-247.

Liang, L.N., He, B., Jiang, G.B., Chen, D.Y., Yao, Z.W., 2004. Evaluation of molluscs as biomonitors to investigate heavy metal contaminations along the Chinese Bohai Sea. Science of the Total Environment 324, 105-113.

Péqueux, A., Bianchini, A., Gilles, R., 1996. Mercury and Osmoregulation in the Euryhaline Crab, Eriocheir sinensis. Comparative Biochemistry and Physiology 113C, 149-155.

Pereira, M.E., Duarte, A.C., Millward, G.E., Abreu, S.N., Vale, C., 1998a. An estimation of industrial mercury stored in sediments of a confined area of the Lagoon of Aveiro (Portugal). Water Science and Technology 37, 125-130.

Pereira, M.E., Duarte, A.C., Millward, G.E., Vale, C., Abreu, S.N., 1998b. Tidal export of particulate mercury from the most contaminated area of Aveiro's Lagoon, Portugal. The Science of the Total Environment 213, 157-163.

Pereira, M.E., Abreu, S.N., Coelho, J.P., Lopes, C.B., Pardal, M.A., Vale, C., Duarte, A.C., 2006. Seasonal fluctuations of tissue mercury contents in the European shore crab Carcinus maenas from low and high contamination areas (Ria de Aveiro, Portugal). Marine Pollution Bulletin 52, 1450-1457.

Raffaelli, D., Conacher, A., McLachlan, H., Emes, C., 1989. The role of epibenthic crustacean predators in an estuarine food web. Estuarine, Coastal and Shelf Science 28, 149-160.

Roméo, M., Frasila, C., Gnassia-Barelli, M., Damiens, G., Micu, D., Mustata, G., 2005 Biomonitoring of trace metals in the Black Sea (Romania) using mussels Mytilus galloprovincialis. Water Research 39, 596-604.

Saiz-Salinas, J.I., Ruiz, J.M., Frances-Zubillaga, G., 1996. Heavy metal levels in intertidal sediments and biota from the Bidasoa estuary. Marine Pollution Bulletin 32, 69-71.

Tchounwou, P.B., Ayensu, W.K., Ninashvili, N., Sutton, D., 2003. Environmental Exposure to Mercury and Its Toxicopathologic Implications for Public Health. Environmental Toxicology 18, 149-175.

Vale, C., Ferreira, A., Caetano, M., Brito, P., 2002. Elemental composition and contaminants in surface sediments of the Mondego river estuary. In: Pardal, M.A., Marques, J.C., Graça, M.A. (Eds.), Aquatic Ecology of the Mondego River Basin. Global Importance of Local Experience. Imprensa da Universidade de Coimbra, Coimbra, pp. 243-256.

Válega, M., Abreu, S., Pato, P., Rocha, L., Gomes, A.R., Pereira, M.E., Duarte, A.C., 2006 Determination of organic mercury in biota, plants and contaminated sediments using a thermal atomic absorption spectrometry technique. Water Air and Soil Pollution 174, 223-234.

Verdelhos, T., Neto, J.M., Marques, J.C., Pardal, M.A., 2005. The effect of eutrophication abatement on the bivalve Scrobicularia plana. Estuarine, Coastal and Shelf Science 63, 261-268.

Watras, C.J., Bloom, N.S., 1992. Mercury and methylmercury in individual zooplankton: implications for bioaccumulation. Limnology and Oceanography 37, 1313-1318 